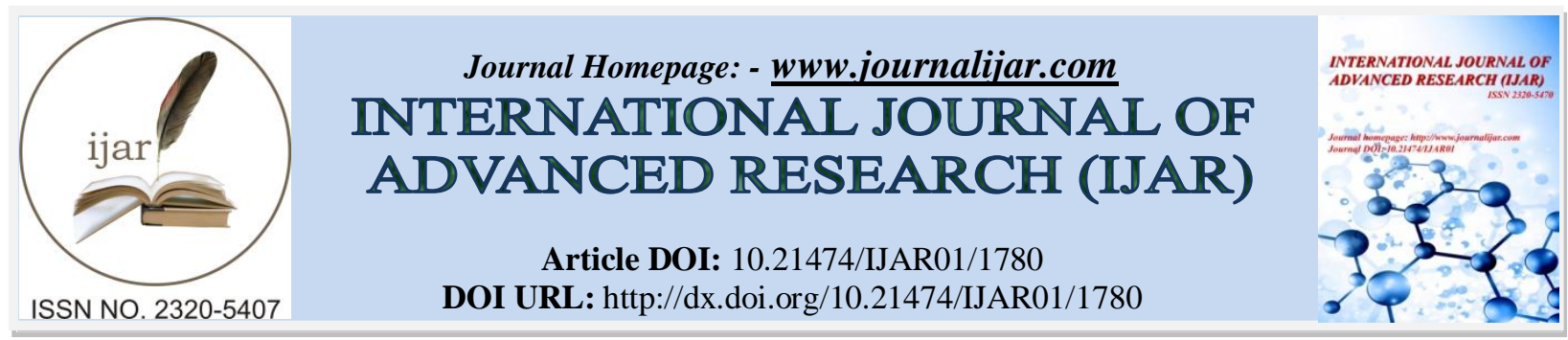

RESEARCH ARTICLE

\title{
SYNTHESIS, SPECTRAL AND BIOLOGICAL STUDIES OF Mn(II), Co(II) AND Cu(II) COMPLEXES OF [2-CHLORO-5-(2,4-DIHYDROXYPHENYL AZO)PHENYL] PHENYLMETHANONE.
}

\author{
S Mini* and V Sadasivan.
}

Department of Chemistry, University College, Thiruvananthapuram 695034 Kerala, India

\section{Manuscript Info}

Manuscript History

Received: 12 August 2016

Final Accepted: 22 September 2016

Published: October 2016

Key words:-

Azodye, ESR spectra, Antitumour study, Antioxidant study.

\section{Abstract}

[2-chloro-5-(2,4-dihydroxyphenyl azo)phenyl] phenylmethanone is an azodye derived from (2-amino-5-chlorophenyl)PhenylMethanone. Three new complexes of this azodye with the metal ions $\mathrm{Mn}(\mathrm{II})$, $\mathrm{Co}(\mathrm{II})$, and $\mathrm{Cu}$ (II) have been prepared and characterized by various analytical methods like microanalytical method, metal estimation, anion estimation, conductance and magnetic moment measurements. These complexes were also characterized by spectral techniques like FTIR, Electronic, and ESR. The azodye and the selected complexes were subjected to antimicrobial study, antioxidant study and anticancer study. The spectral and analytical data confirms that the azodye acting as tridentate ligand with the metal ions $\mathrm{Mn}(\mathrm{II}), \mathrm{Co}(\mathrm{II})$, and $\mathrm{Cu}(\mathrm{II})$ and. The ligand and the metal ions in the complexes are found to be 1:1 ratio.

Copy Right, IJAR, 2016,. All rights reserved.

\section{Introduction:-}

Azodyes and their metal complexes are very important compounds receiving attention in scientific research and industry. These compounds are highly coloured and used as dyes and pigments for long time (Pooja, T., 2004). Azodyes have wide spread application as redox, acidbase indicators, metalochrome and histological stains have attracted many investigators. Azo compounds are also used as inkjet printers and electro-optical devices. Synthetic dyes containing $-\mathrm{N}=\mathrm{N}$ - groups are known as non-biodegradable in aerobic condition (Park, H., et al., 2003).

(2-amino-5-chlorophenyl)PhenylMethanone \{2-amino-5-chloro benzophenone\}, 2-Aminobenzophenone derivatives are important compounds because of their application in heterocyclic synthesis and medicines (Mini, S., et al., 2015). This compound is used as the starting material for the synthesis of benzodiazepam. All the drugs synthesized from 2-aminobenzophenone possess CNS activity (Rajesh K. Singh, et al., 2011). So the derivatives were considered to be of our interest because of having the CNS activity of benzodiazepines to obtain drugs with high therapeutic index than diazepam.

The present work deals with the synthesis and characterization of some new complexes of $\mathrm{Cu}$ (II), $\mathrm{Co}$ (II), and $\mathrm{Mn}$ (II) ions with the azodye, [2-Chloro-5-(2,4-dihydroxyphenylazo)phenyl]phenylmethanone, derived from 2-amino-5chlorobenzophenone and resorcinol.

Corresponding Author:- S Mini.

Address:- Department of Chemistry, University College, Thiruvananthapuram 695034 Kerala, India. 


\section{Experimental:-}

\section{Materials and methods:-}

The reagents 2-amino-5-chlorobenophenone, resorcinol, were purchased from their manufactures (BDH-AR, MerckGR) and used as such for the synthesis of ligand. All of the metal salts used for the preparation of the complexes were AR grade samples.

Estimation of the metal and chloride present in the complexes were done by standard methods (Vogel, A.I., 1989). Elemental analyses were determined by CHNS analysis at SAIF, Cochin. The molar conductivity measurements were made using Systronics direct reading conductivity meter. Infrared spectra were recorded on a Perkin-Elmer Spectrum 65 infrared spectrophotometer using $\mathrm{KBr}$ pellets. ESR spectra of $\mathrm{Cu}(\mathrm{II})$ complexes in solid state, solution and frozen states were recorded on a Varian-E-112 spectrophotometer at X- band using TCNE as marker at the SAIF, IIT, Mumbai. The magnetic moments were measured at room temperature on a Sherwood Scientific Magnetic Susceptibility balance. Electronic absorption spectral measurements of the ligand and the complexes in methanol were recorded on a Perkin-Elmer Lamda 25 UV-Visible spectrophotometer.

\section{Preparation of [2-chloro-5-(2,4-dihydroxy phenylazo) phenyl] phenylmethanone [RABP]:-}

The ligand RABP is prepared by diazotizing 2-amino-5-chlorobenzophenone and coupling with resorcinol (Mini S., et al., 2013). The resulting product was recrystallised from DMF.

\section{Preparation of complexes:-}

The complexes of [2-chloro-5-(2,4-dihydroxyphenylazo)phenyl]-phenyl methanone [RABP] with $\mathrm{Mn}(\mathrm{II}), \mathrm{Co}(\mathrm{II})$, and $\mathrm{Cu}(\mathrm{II})$, were prepared by the following general method. A methanolic solution of the corresponding metal salt $\left[\mathrm{CuCl}_{2} \cdot 2 \mathrm{H}_{2} \mathrm{O}, \mathrm{Mn}(\mathrm{Ac})_{2} \cdot 4 \mathrm{H}_{2} \mathrm{O}, \mathrm{Co}\left(\mathrm{NO}_{3}\right)_{2} \cdot 6 \mathrm{H}_{2} \mathrm{O}\right]$ was added to a solution of RABP in acetone. The metal salt to ligand molar ratio was kept 1:1. The resulting mixture was stirred and refluxed for 3-4 hours. The solution thus obtained was concentrated to get the solid complex. It was filtered, washed with ethanol-acetone mixture, dried and kept in a desiccator over anhydrous $\mathrm{CaCl}_{2}$.

\section{Results and Discussion:-}

All complexes are stable non-hygroscopic solids and are soluble in DMSO, DMF and $\mathrm{CHCl}_{3}$. The analytical data of the complexes of RABP are presented in Table 1. The analytical data obtained are in good agreement with the calculated values which suggest that the metal and the ligand are coordinated in the ratio 1:1. Based on the analytical data, $[\mathrm{Cu}(\mathrm{RABP}) \mathrm{Cl}]$, [Co(RABP) $\left.\left(\mathrm{NO}_{3}\right)\left(\mathrm{H}_{2} \mathrm{O}\right)_{2}\right]$, and $\left[\mathrm{Mn}(\mathrm{RABP})(\mathrm{Ac})\left(\mathrm{H}_{2} \mathrm{O}\right)_{2}\right]$ are the empirical formulae suggested for the complexes. The molar conductance at room temperature was determined using $10^{-3} \mathrm{M}$ solutions of the complexes in the solvents methanol and DMF. These values support the non-electrolytic nature of all the complexes (Geary, W. J., 1971). The conductance values along with the magnetic moments are also shown in Table 1.

\section{Infrared spectra:-}

The infrared spectra of the ligand and the metal complexes were recorded in the range 4000-400 $\mathrm{cm}^{-1}$. The important spectral bands and the tentative assignments are given in Table 2. The infrared spectra of the complexes exhibit characteristic absorptions of all functional groups of ligand but at a shifted position in the case of coordinated groups. The strong absorption band shown by the ligand RABP at $1460 \mathrm{~cm}^{-1}$ corresponds to $\mathrm{V}_{\mathrm{N}=\mathrm{N}}$ suffers a shift to higher wave number may taken as an evidence for the participation of $-\mathrm{N}=\mathrm{N}$ group in coordination (Gaber, $\mathrm{M}$., et al., 2008). This is supported by the appearance of new band in the region of $423-467 \mathrm{~cm}^{-1}$ assignable to $v_{\mathrm{M}-\mathrm{N}}$ (Beecroft, B., et al., 1974). The considerable shift shown by strong $v_{\mathrm{C}=\mathrm{O}}$ band at $1619 \mathrm{~cm}^{-1}$ of RABP to lower value in complexes is a clear evidence for the participation of $>\mathrm{C}=\mathrm{O}$ in coordination (Radhakrishnan, P.K., et al., 1984). The appearance of new bands in the region $503-523 \mathrm{~cm}^{-1}$ assignable to $v_{\mathrm{M}-\mathrm{O}}$ confirms the involvement $>\mathrm{C}=\mathrm{O}$ in coordinate bond formation (Speca, A.N., et al., 1974).

The two hydroxyl groups in the resorcinol part of the ligand exhibit a broad band at $3418 \mathrm{~cm}^{-1}$. From the anion analysis, it is found that one chloride ion is present per copper complex molecule. This indicates that RABP is acting as tridentate univalent anion. This is achieved via deprotonation of one of the $\mathrm{OH}$ group of the resorcinol part of the ligand. The broad peak shown by $\mathrm{Cu}$ (II) complex at $3320 \mathrm{~cm}^{-1}$ may due to the uncoordinated phenolic $\mathrm{OH}$ group.

As in the case of $\mathrm{Cu}(\mathrm{II})$, the IR band shown by $\mathrm{Ni}(\mathrm{II})$ complex at $3352 \mathrm{~cm}^{-1}$ may due to the presence of one uncoordinated hydroxyl group in the resorcinol part of the ligand. 
In $\operatorname{Co}(\mathrm{II})$ and $\mathrm{Mn}$ (II) complexes the broad band appeared respectively at 3411 and $3344 \mathrm{~cm}^{-1}$, may due to the uncoordinated phenolic $\mathrm{OH}$ and $\mathrm{V}_{\mathrm{OH}}$ of coordinated water. It is supported by the univalent behavior of RABP and the bands corresponding to $\mathrm{V}_{\mathrm{HOH}}$ (def) at 1627 and $1631 \mathrm{~cm}^{-1}$ and $\mathrm{V}_{\mathrm{HOH}}$ (rock) at $948,949 \mathrm{~cm}^{-1}$ respectively (Nakamoto, K., 1970). In the newly synthesized Co(II) complex, the presence of two medium intensity bands at $1380 \mathrm{~cm}^{-1}$ and $1225 \mathrm{~cm}^{-1}$ due to $v_{1}$ and $v_{2}$ vibration and $1485 \mathrm{~cm}^{-1}$ is due to $v_{4}$ vibration respectively. The frequency separation $v_{4}-v_{1}$ is in the range $100-150 \mathrm{~cm}^{-1}$ is reasonable to infer that nitrate group is coordinated as monodentate anion in the Co(II) complex of RABP. In the present complex of $\mathrm{Mn}$ (II) the acetate group act as monodentate ligand. This is evidenced by the difference of $215 \mathrm{~cm}^{-1}$ between $v_{\mathrm{COO}}$ (asym) $1621 \mathrm{~cm}^{-1}$ and $v_{\mathrm{COO}}$ (sym) $1406 \mathrm{~cm}^{-}$ ${ }^{1}$ vibrations.

\section{Electronic spectra:-}

The electronic spectral data of different metal complexes with RABP are presented in Table 3. Copper (II) being a $\mathrm{d}^{9}$ system is highly susceptible to Jahn-Teller distortion and perfectly octahedral configuration can never be expected (Sadasivan, V., 2004). Generally a distorted octahedral, square planar or tetrahedral configuration is formed. The electronic spectra of $\mathrm{Cu}$ (II) complex of RABP shows a broad band around $430 \mathrm{~nm}$ corresponds to $\mathrm{n} \rightarrow \pi^{*}$ transition of ligand RABP. Two weak bands present at $668 \mathrm{~nm}$ and $525 \mathrm{~nm}$ assigned to ${ }^{2} \mathrm{~B}_{1 \mathrm{~g}} \rightarrow{ }^{2} \mathrm{~B}_{2 \mathrm{~g}}$ and ${ }^{2} \mathrm{~B}_{1 \mathrm{~g}} \rightarrow{ }^{2} \mathrm{E}_{\mathrm{g}}$ transitions, suggests square planar geometry for the $\mathrm{Cu}$ (II) complex (Rajendra K. Jain and Anand P. Mishra, 2012). The newly synthesized Mn(II) complex exhibit a very intense band around $438 \mathrm{~nm}$ and a very faint shoulder around $550 \mathrm{~nm}$. The intense peak may be attributed to the ligand absorption and weak shoulder may due to the overlapping of spin forbidden d-d transition with the ligand absorption. The newly synthesized Co(II) complex shows three absorption bands at $691 \mathrm{~nm} 580 \mathrm{~nm}$ and $428 \mathrm{~nm}$. These are attributed to ${ }^{4} \mathrm{~T}_{1 \mathrm{~g}}(\mathrm{~F}) \rightarrow{ }^{4} \mathrm{~A}_{2 \mathrm{~g}}(\mathrm{~F}),{ }^{4} \mathrm{~T}_{1 \mathrm{~g}}(\mathrm{~F}) \rightarrow{ }^{4} \mathrm{~T}_{1 \mathrm{~g}}(\mathrm{P})$ and $\| \mathrm{n} \rightarrow \pi^{*}$ transition originated from the ligand. These bands support an octahedral geometry for the complex (Ballhausen, C.J., 1979).

\section{ESR spectrum:-}

In the ESR spectrum of the newly synthesized $\mathrm{Cu}$ (II) complex, there is an absorption around $3200 \mathrm{G}$, characteristic of $\mathrm{Cu}^{2+}$ species. The absence of half- field peak around $1600 \mathrm{G}$ corresponding to $\Delta \mathrm{Ms}= \pm 2$ rules out the $\mathrm{Cu}-\mathrm{Cu}$ interaction in this complex (Sharma A.L., et al., 2001). The ESR spectra of the $\mathrm{Cu}$ (II) complex in polycrystalline state and in DMF solution and at LNT are shown in fig: 1 and 2. The spectrum taken at the frozen state shows hyperfine splitting in the parallel component with low intensities in the low field region and one intense peak at the high field region. The $\mathrm{G}$ value is calculated using the relation $\quad G=\frac{g_{\square}-2.0027}{g_{\perp}-2.0027}$

If the $\mathrm{G}$ value is larger than four, the exchange interaction is negligible because the tetragonal axes are aligned parallel or are slightly misaligned; and the unpaired electrons are present in the $d_{x^{2}-y^{2}}$ orbital. If the $G$ value is less than four, the exchange interaction is considerable and the local tetragonal axes are misaligned (Benial, A.M.F., et al., 2000).

The copper (II) complex of RABP shows the $\mathrm{g}_{\|}$value 2.38 and $\mathrm{g}_{\perp}$ value 2.04 . These values indicate that the unpaired electron is localized in the $\mathrm{d}_{\mathrm{x}^{2}-\mathrm{y}^{2}}$ orbital of copper ion. $\mathrm{g}_{\text {avg }}$ calculated is 2.15 and $\mathrm{G}$ value calculated using this $\mathrm{g}_{\square}$ and $\mathrm{g}_{\perp}$ value is 10.09 indicates negligible exchange interaction of $\mathrm{Cu}-\mathrm{Cu}$ in the complex. The covalency parameter $\alpha^{2}$ calculated using the above mentioned equation is 0.83 , which is $<1.0$, indicates that the complex has some covalent character in the ligand environment (Raman, N., et al., 2004). The ESR spectral data of $\mathrm{Cu}(\mathrm{II})$ complex of RABP is given in Table 4.

\section{Antimicrobial Activity:-}

The antibacterial and antifungal activity results of ligands and their metal complexes were presented in Table 5 and 6. A comparative study of the ligands and their metal complexes indicate that most of the metal chelates exhibit higher antimicrobial activity than those of the free ligands. The activities of these complexes depend on the structure and orientation of various moieties of chelates. The number of binding sites and the effect of chelation may be responsible for the increased antimicrobial activity of the complexes. Besides this, many other factors such as solubility, dipole moment and conductivity of complexes also may be the reason for remarkable antimicrobial 
activities of the complexes (Coombs, R.V., et al., 2005; Chohan, Z.H., et al., 2001, 2010). The antimicrobial activities of RABP and its complexes are shown in fig: 3 and 4.

\section{Antitumour activity:-}

The antitumour activity of Co(II) complex was determined by MTTassay. The result obtained from MTT assay method is recorded in Table 7. It is clear that as the concentration of the drug increases relative cell viability decreases. The cell viability of the complex is shown in fig:5

\section{Antioxidant study:-}

The antioxidant values of the ligand and Mn(II) complex studied by DPPH assay are shown in Table 8. These values indicate that the antioxidant activity of the ligand have been enhanced on complexation with $\mathrm{Mn}^{2+}$ ion and the complex $\left[\mathrm{Mn}(\mathrm{RABP})(\mathrm{Ac})\left(\mathrm{H}_{2} \mathrm{O}\right)_{2}\right]$ has comparable activity to the standard.

Table 1:- Analytical data of RABP complexes.

\begin{tabular}{|c|c|c|c|c|c|c|c|c|}
\hline \multirow[t]{2}{*}{ Complex } & \multirow[t]{2}{*}{ Metal\% } & \multirow[t]{2}{*}{ Anion \% } & \multirow[t]{2}{*}{$\mathrm{C} \%$} & \multirow[t]{2}{*}{$\mathrm{N} \%$} & \multirow[t]{2}{*}{$\mathrm{H} \%$} & \multirow[t]{2}{*}{$\mu \mathrm{eff}$} & \multicolumn{2}{|c|}{ Conductivity } \\
\hline & & & & & & & Methanol & $\overline{\mathrm{DMF}}$ \\
\hline$[\mathrm{Cu}(\mathrm{RABP}) \mathrm{Cl}]$ & \begin{tabular}{|l|}
14.1 \\
$(14.5)$
\end{tabular} & $\begin{array}{l}7.9 \\
(7.8) \\
\end{array}$ & $\begin{array}{l}59.6 \\
(59.3)\end{array}$ & $\begin{array}{l}6.2 \\
(6.4)\end{array}$ & $\begin{array}{l}2.6 \\
(2.9)\end{array}$ & 1.8 & 15.4 & 32.6 \\
\hline$\left[\mathrm{Co}(\mathrm{RABP})\left(\mathrm{NO}_{3}\right)\left(\mathrm{H}_{2} \mathrm{O}\right)_{2}\right]$ & $\begin{array}{l}11.6 \\
(11.2)\end{array}$ & - & $\begin{array}{l}44.8 \\
(45.0)\end{array}$ & $\begin{array}{l}5.5 \\
(5.9)\end{array}$ & $\begin{array}{l}3.1 \\
(3.4)\end{array}$ & 5.1 & 21.8 & 18.2 \\
\hline$\left[\mathrm{Mn}(\mathrm{RABP})(\mathrm{Ac})\left(\mathrm{H}_{2} \mathrm{O}\right)_{2}\right]$ & $\begin{array}{l}10.9 \\
(11.0) \\
\end{array}$ & - & $\begin{array}{l}45.4 \\
(45.2) \\
\end{array}$ & $\begin{array}{l}5.5 \\
(5.4) \\
\end{array}$ & $\begin{array}{l}2.3 \\
(2.5) \\
\end{array}$ & 6.7 & 21.7 & 11.8 \\
\hline
\end{tabular}

$A c=$ acetate

Table 2:- IR Spectral bands of RABP and its complexes

\begin{tabular}{|l|l|l|l|l|}
\hline RABP & {$[\mathrm{Cu}(\mathrm{RABP}) \mathrm{Cl}]$} & {$\left[\mathrm{Co}(\mathrm{RABP})\left(\mathrm{NO}_{3}\right)\left(\mathrm{H}_{2} \mathrm{O}\right)_{2}\right]$} & {$\left[\mathrm{Mn}(\mathrm{RABP})(\mathrm{Ac})\left(\mathrm{H}_{2} \mathrm{O}\right)_{2}\right]$} & Assignments \\
\hline 3418 & 3320 & ---- & --- & $v_{\mathrm{OH}}$ phenolic \\
& & 3411 & 3344 & $v_{\mathrm{OH}}$ phenolic \& water \\
\hline 2873 & 2875 & 2873 & 2872 & $\begin{array}{l}v_{\mathrm{C}-\mathrm{H}} \text { (aromatic } \\
\text { stretching })\end{array}$ \\
\hline 1619 & 1594 & 1596 & 1594 & $v_{\mathrm{C}=\mathrm{O}}$ \\
\hline- & - & - & 1625 & $v_{\mathrm{COO}}($ asy $)$ \\
\hline 1460 & 1484 & 1478 & 1475 & $v_{\mathrm{N}=\mathrm{N}}$ \\
\hline- & - & - & 1406 & $v_{\mathrm{COO}}($ sym $)$ \\
\hline- & - & 1380 & - & $v_{1} \mathrm{NO}_{3}$ coordinated \\
\hline- & - & 1225 & - & $v_{2} \mathrm{NO}_{3}$ coordinated \\
\hline 832 & 830 & 824 & 832 & $v_{\mathrm{C}-\mathrm{H}}$ aromatic bond \\
\hline- & 450 & 445 & 462 & $v_{\mathrm{M}-\mathrm{N}}$ bond \\
\hline- & 510 & 509 & 517 & $v_{\mathrm{M}-\mathrm{O}}$ bond \\
\hline
\end{tabular}

Table 3:- Electronic spectral bands of RABP and its complexes.

\begin{tabular}{|l|l|l|}
\hline Compound & $\lambda_{\max } \mathrm{nm}$ & Assignments \\
\hline \multirow{4}{*}{ RABP } & 426 & $\mathrm{n} \rightarrow \pi^{*}$ \\
\cline { 2 - 3 } & 262 & $\pi \rightarrow \pi^{*}$ \\
\hline \multirow{4}{*}[\mathrm{Cu}(\mathrm{RABP})\mathrm{Cl}]{} & 430 & $\mathrm{n} \rightarrow \pi^{*}$ \\
\cline { 2 - 3 } & 525 & ${ }^{2} \mathrm{~B}_{1 \mathrm{~g}} \rightarrow{ }^{2} \mathrm{E}_{\mathrm{g}}$ \\
\cline { 2 - 3 } & 668 & ${ }^{2} \mathrm{~B}_{1 \mathrm{~g}} \rightarrow{ }^{2} \mathrm{~B}_{2 \mathrm{~g}}$ \\
\hline \multirow{2}{*}[\mathrm{Co}(\mathrm{RABP})\mathrm{NO}_{3}(\mathrm{H}_{2}\mathrm{O})_{2}]{} & 428 & $\mathrm{n} \rightarrow \pi^{*}$ \\
\cline { 2 - 3 } & 580 & ${ }^{4} \mathrm{~T}_{1 \mathrm{~g}}(\mathrm{~F}) \rightarrow{ }^{4} \mathrm{~T}_{1 \mathrm{~g}}(\mathrm{P})$ \\
\cline { 2 - 3 } & 691 & ${ }^{4} \mathrm{~T}_{1 \mathrm{~g}}(\mathrm{~F}) \rightarrow{ }^{4} \mathrm{~A}_{2 \mathrm{~g}}(\mathrm{~F})$ \\
\hline \multirow{2}{*}[\mathrm{Mn}(\mathrm{RABP})\mathrm{Ac}(\mathrm{H}_{2}\mathrm{O})_{2}]{} & 438 & $\mathrm{n} \rightarrow \pi^{*}$ \\
\cline { 2 - 3 } & 550 & $\mathrm{~d} \rightarrow \mathrm{d}$ \\
\hline
\end{tabular}


Table 4:- ESR Spectral data of $[\mathrm{Cu}(\mathrm{RABP}) \mathrm{Cl}]$

\begin{tabular}{|c|c|c|c|c|c|c|}
\hline Complex & $\mathbf{g}_{\square}$ & $\mathbf{g}_{\perp}$ & $\mathbf{g}_{\text {avg }}$ & $\mathbf{A}_{\square}$ & $\mathbf{G}$ & $\boldsymbol{\alpha}^{\mathbf{2}}$ \\
\hline$[\mathrm{Cu}(\mathrm{RABP}) \mathrm{Cl}]$ & 2.38 & 2.04 & 2.15 & 0.0170 & 10.09 & 0.832 \\
\hline
\end{tabular}

Table 5:- Antibacterial activity of RABP and its complexes.

\begin{tabular}{|l|c|c|}
\hline \multicolumn{1}{|c|}{ Compound } & Escherichia coli & Staphylococcus aureus \\
\hline Chloroform & $\mathrm{NZ}$ & $\mathrm{NZ}$ \\
\hline RABP & $0.8 \mathrm{~cm}$ & $\mathrm{NZ}$ \\
\hline$[\mathrm{Cu}(\mathrm{RABP}) \mathrm{Cl}]$ & $1.1 \mathrm{~cm}$ & $0.8 \mathrm{~cm}$ \\
\hline$\left[\mathrm{Co}(\mathrm{RABP})\left(\mathrm{NO}_{3}\right)\left(\mathrm{H}_{2} \mathrm{O}\right)_{2}\right]$ & $0.7 \mathrm{~cm}$ & $\mathrm{NZ}$ \\
\hline$\left[\mathrm{Mn}(\mathrm{RABP})(\mathrm{Ac})\left(\mathrm{H}_{2} \mathrm{O}\right)_{2}\right]$ & $\mathrm{NZ}$ & $0.9 \mathrm{~cm}$ \\
\hline
\end{tabular}

Table 6:- Antifungal activity of RABP and its complexes.

\begin{tabular}{|l|c|c|}
\hline \multicolumn{1}{|c|}{ Compound } & Aspergillus Niger & Candida Albicans \\
\hline Chloroform & $\mathrm{NZ}$ & $\mathrm{NZ}$ \\
\hline $\mathrm{RABP}$ & $\mathrm{NZ}$ & $\mathrm{NZ}$ \\
\hline$[\mathrm{Cu}(\mathrm{RABP}) \mathrm{Cl}]$ & $\mathrm{NZ}$ & $0.7 \mathrm{~cm}$ \\
\hline$\left[\mathrm{Co}(\mathrm{RABP})\left(\mathrm{NO}_{3}\right)\left(\mathrm{H}_{2} \mathrm{O}\right)_{2}\right]$ & $\mathrm{NZ}$ & $\mathrm{NZ}$ \\
\hline$\left[\mathrm{Mn}(\mathrm{RABP})(\mathrm{Ac})\left(\mathrm{H}_{2} \mathrm{O}\right)_{2}\right]$ & $\mathrm{NZ}$ & $\mathrm{NZ}$ \\
\hline
\end{tabular}

NZ- No zone

Table 7:- The percent viability of cells as determined by MTT assay method for [Co(RABP $\left.) \mathrm{NO}_{3}\left(\mathrm{H}_{2} \mathrm{O}\right)_{2}\right]$

\begin{tabular}{|l|c|c|}
\hline \multicolumn{1}{|c|}{ Sample concentration $(\boldsymbol{\mu g} / \mathbf{m l})$} & OD at 540 $\mathbf{~ m}$ & \% viability \\
\hline Control & 0.4522 & 100 \\
\hline$\left[\mathrm{Co}(\mathrm{RABP})\left(\mathrm{NO}_{3}\right)\left(\mathrm{H}_{2} \mathrm{O}\right)_{2}\right]$ & & 67.42 \\
\hline 10 & 0.3049 & 50.99 \\
\hline 50 & 0.2306 & 28.77 \\
\hline 100 & 0.1301 & \\
\hline
\end{tabular}

Table 8:- Percentage inhibition of antioxidant activity of RABP and their Mn(II) complex Optical density of control at $517 \mathrm{~nm}$ is 0.389

\begin{tabular}{|l|c|c|}
\hline \multicolumn{1}{|c|}{ Sample concentration $(\boldsymbol{\mu g} / \mathbf{m l})$} & OD at 517nm & \% inhibition \\
\hline RABP & 0.274 & 29.56 \\
\hline 12.5 & 0.185 & 52.44 \\
\hline 25 & 0.180 & 53.72 \\
\hline 50 & 0.176 & 54.75 \\
\hline 100 & 0.162 & 58.35 \\
\hline 200 & \multicolumn{2}{|c|}{} \\
\hline$\left[\mathbf{M n}(\mathbf{R A B P})(\mathbf{A c})\left(\mathbf{H}_{\mathbf{2}} \mathbf{O}\right)_{2}\right]$ & 0.220 & 43.44 \\
\hline 12.5 & 0.181 & 53.47 \\
\hline 25 & 0.108 & 72.23 \\
\hline 50 & 0.097 & 75.06 \\
\hline 100 & 0.090 & 76.86 \\
\hline 200 & & \\
\hline
\end{tabular}




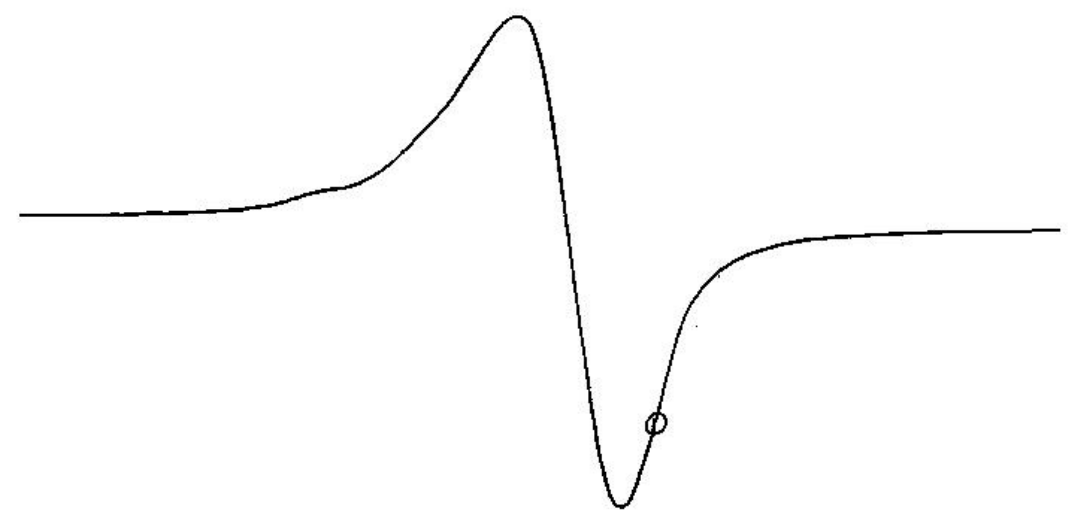

TCNE

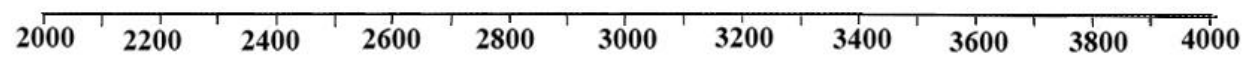

$\mathrm{H}$ in Gauss $\rightarrow$

Fig 1:- Polycrystalline ESR Spectrum of [Cu(RABP)Cl].
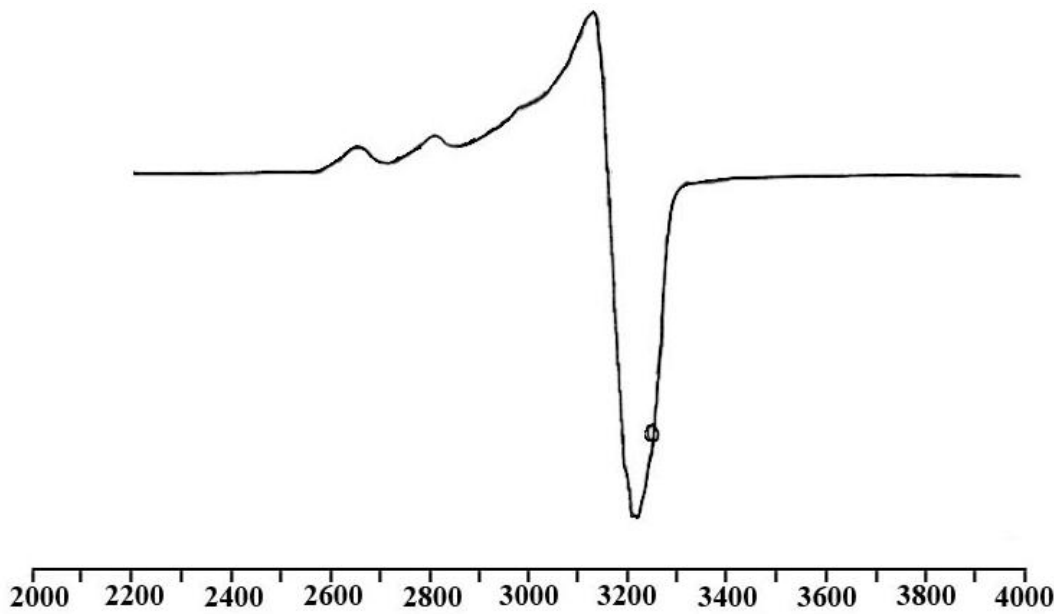

Fig 2:- ESR Spectrum of $[\mathrm{Cu}(\mathrm{RABP}) \mathrm{Cl}]$ in $\mathrm{DMF}$ at $77 \mathrm{~K}$. 

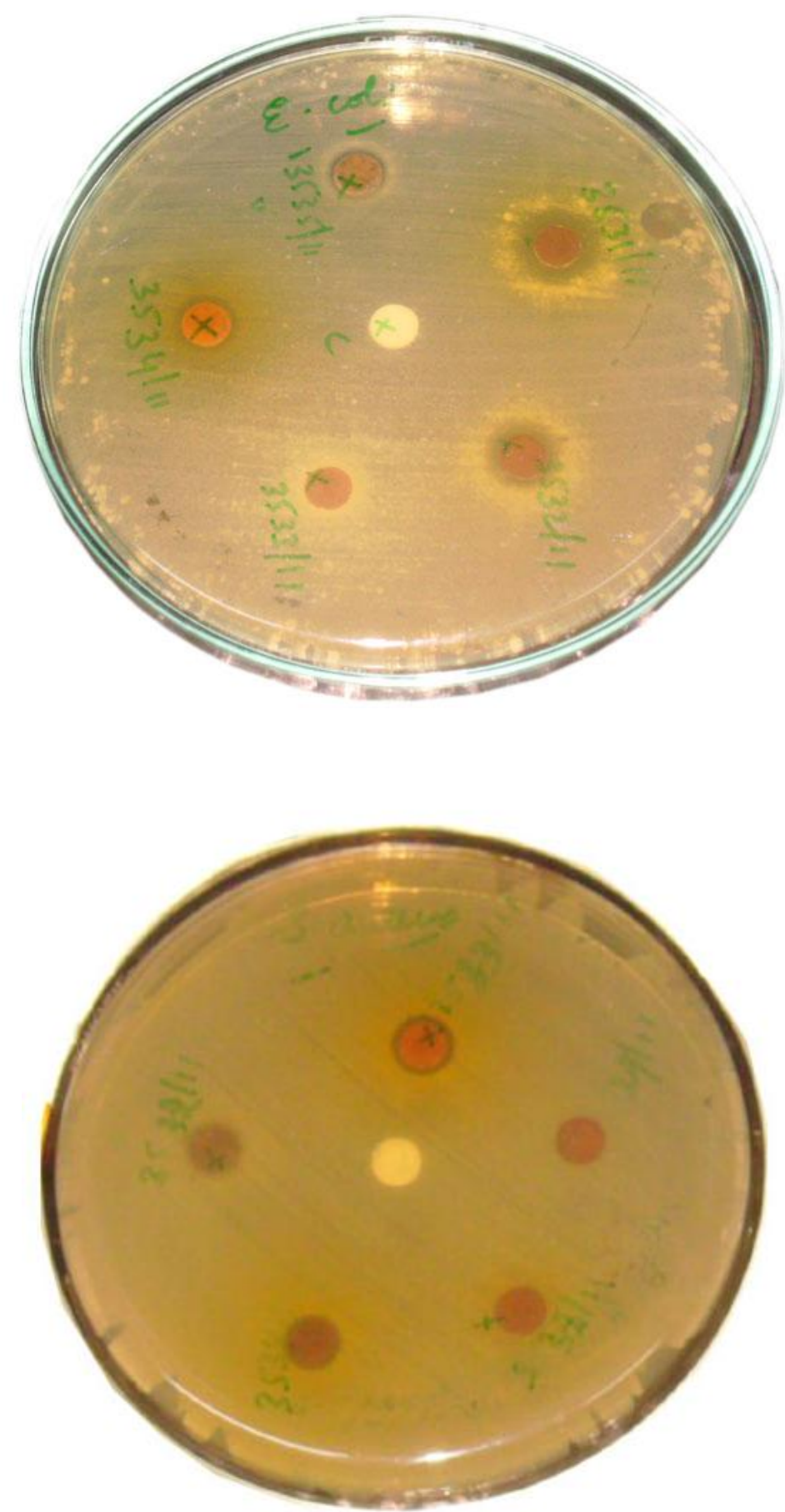

Fig 3:- Antibacterial activity of RABP and its complexes against Escherichia coli and Staphylococcus aureus. 

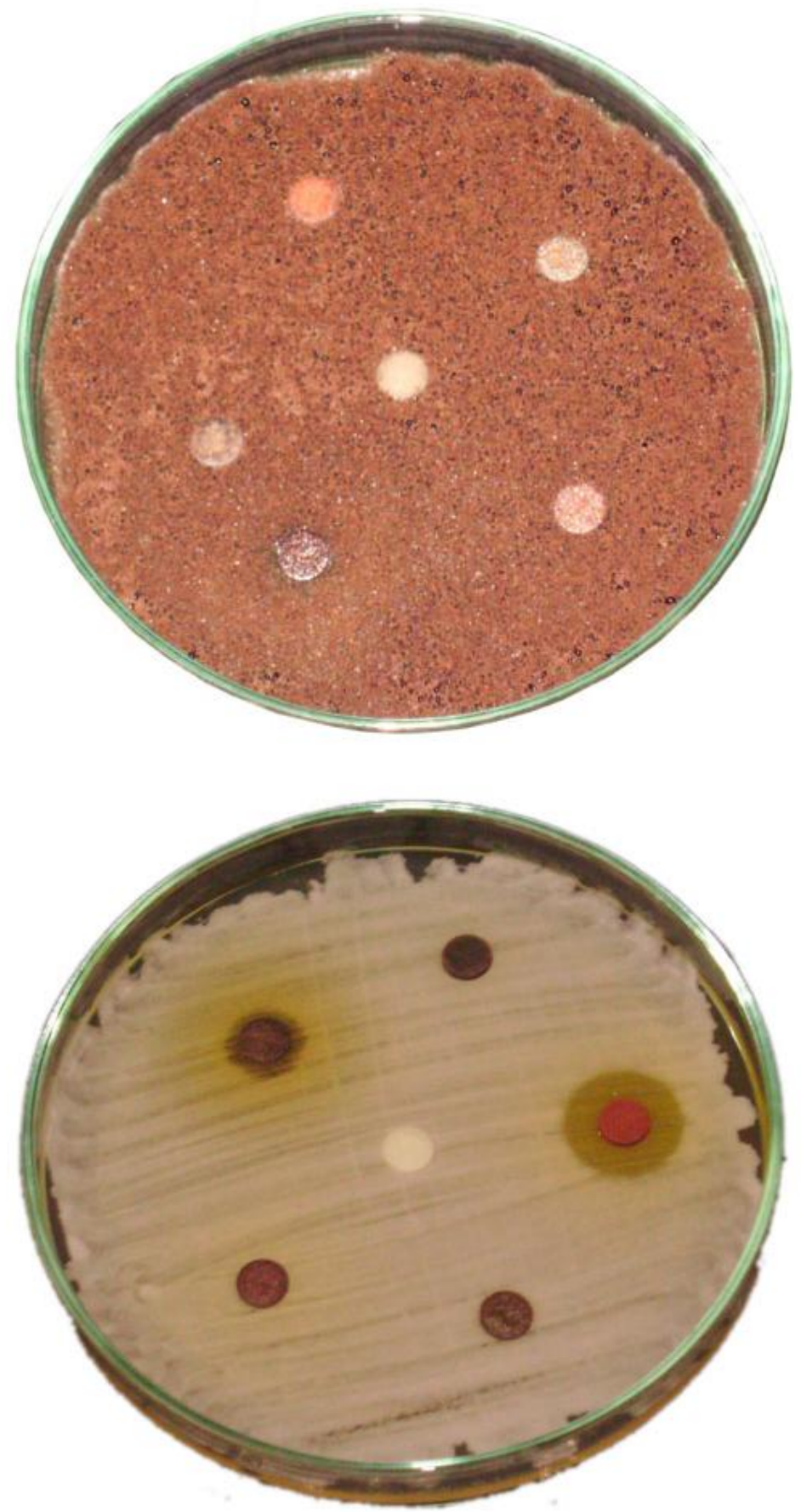

Fig 4:- Antifungal activity of RABP and its complexes against Candida albicans and Aspergillus niger 


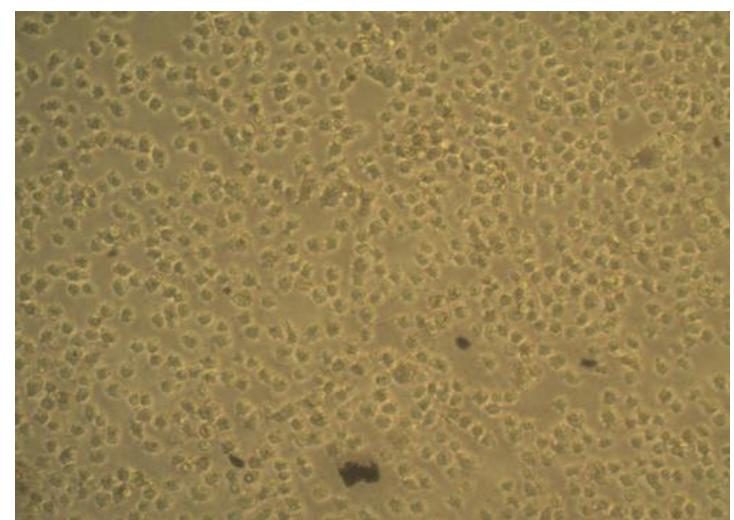

$10 \mu \mathrm{g} / \mathrm{ml}$

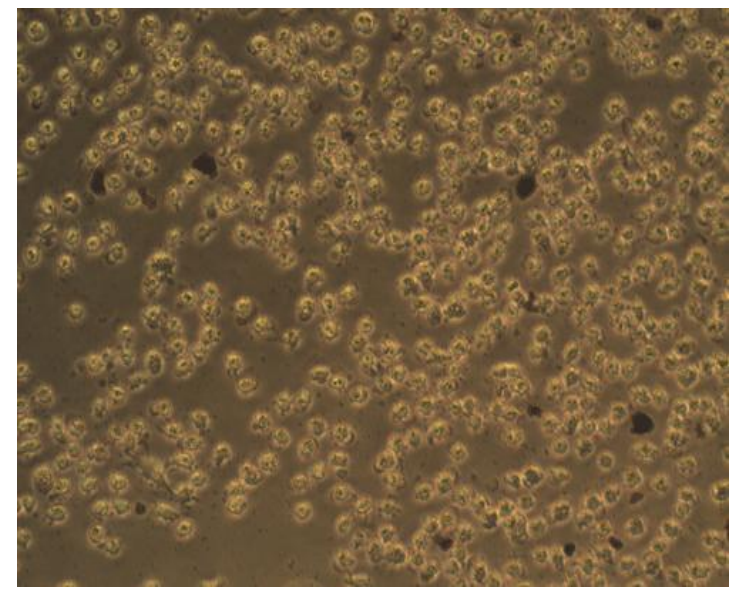

\section{$10 \mu \mathrm{g} / \mathrm{ml}$}

Fig 5:- Imag

\section{Fig}

\section{Conclusion:-}

Three complexes of [2-Chloro-5-(2,4-dihydroxyphenylazo)phenyl]phenyl methanone, (RABP) with $\mathrm{Mn}$ (II), $\mathrm{Co}(\mathrm{II})$, and $\mathrm{Cu}(\mathrm{II})$, were synthesized and characterized by physico-chemical studies. On the basis of spectral and physicochemical analyses, square planar and octahedral geometries have been proposed for the complexes. IR spectral data reveals that RABP is acting as univalent in all the complexes. It acts as tridentate manner through nitrogen and oxygen. The ligand is coordinated in 1:1 with the metal ions. All the complexes show non-electrolytic behavior. With the help of all analyses the complexes are formulated as $[\mathrm{Cu}(\mathrm{RABP}) \mathrm{Cl}]$, $\left[\mathrm{Co}(\mathrm{RABP})\left(\mathrm{NO}_{3}\right)\left(\mathrm{H}_{2} \mathrm{O}\right)_{2}\right]$, and $\left[\mathrm{Mn}(\mathrm{RABP})(\mathrm{Ac})\left(\mathrm{H}_{2} \mathrm{O}\right)_{2}\right]$.

\section{Acknowledgments:-}

We express our sincere thanks to to the Department of Chemistry, University College, Thiruvananthapuram for instrumental facilities under FIST DST and STIC, Cochin University of Science and Technology, SAIF, IIT Bombay, Biogenics, Thiruvananthapuram for analytical facilities. 


\section{References:-}

1. Pooja, T.; Malay, C. (2004), Decolourisation of metal complex Azodyes and treatment of a dye house waste by modified photo Fenton (UV-Vis/Ferri oxalated $\mathrm{H}_{2} \mathrm{O}_{2}$ ) Process' Indian J.Eng.Mater. Sci.,11, ,499-504.

2. Park, H.; Choi, W.,(2003), Visible light and Fe(III)- mediated degradation of Acid Orange 7 in the absence of H2O2 J. Photochem. Photobiol., 159, 241-247.

3. 3. Mini, S.; Sadasivan, V.; Meena, S.S. and Pramod Bhatt., (2015), Synthesis and Spectral Studies of Metal Complexes of a Schiff Base Derived from (2-amino-5-chlorophenyl) Phenyl Methanone, Spectro. Chim.Acta. , vol (15), 598-604

4. Rajesh K. Singh, Sonia Devi, Prasad, D.N.,(2011), Synthesis physicochemical and biological evaluation of 2amino-5-chloro benzophenone derivatives as potent skeletal muscle relaxants, Arab. J. Chem.,

5. Vogel, A.I., (1989), 'Text book of Practical Organic Chemistry', Longman,

6. Mini, S.; Meena, S.S.; Pramod Bhatt, Sadasivan, V. and Vidya, V.G.,(2013), Synthesis and characterization of $\mathrm{Fe}$ (III) complex of an azo dye derived from (2-amino-5-chlorophenyl) phenyl methanone, AIP Conf.Proc., 1536, 1011-1012.

7. Geary, W.J., (1971), The use of conductivity measurements in organic solvent for the characterization of coordination compounds, Cood. Chem. Rev., 7, 81-122.

8. Gaber, M.; Hassanein, A. M. ; Lotfalla, A. A.,(2008), Synthesis and Characterisation of $\mathrm{Co}(\mathrm{II}), \mathrm{Ni}(\mathrm{II})$ and $\mathrm{Cu}(\mathrm{II})$ complexes involving hydroxy antipyrine azodyes. J. Mol. Struct., 875, 2 322-328.

9. Beecroft, B.; Campbell, M.J.M.; Grzeskowiak, R.;(1974), Complexes of semicarbazones and thiosemicarbazones with nickel(II), J. Inorg. Nucl. Chem., 36, 55-59.

10. Radhakrishnan, P.K., Indrasenan, P., Ramachandran Nair, C.G., (1984), Complexes of lanthanide nitrates with 4n-(2'-hydroxy benzylidene)-aminoantipyrine, Polyhedron, 3, 67-70.

11. Speca, A.N., Karayannis, N.M.; Pytlewski, L.L.,(1974), Chromium(III) and iron(III) perchlorate with the mono-N-oxides of 2,2'-bipyridine and 1,10-phenanthroline, Inorg. Chim. Acta, 9, 87-93.

12. Nakamoto, K.,(1970), 'Infrared Spectra of Inorganic and Coordination Compound's, New York, John Wiley and sons.

13. Sadasivan, V.,(2004), ' Physico-chemical studies on some 3d-Transition metal complexes' $\mathrm{Ph} . \mathrm{D}$ Thesis.

14. Rajendra K. Jain; Anand. P. Mishra, (2012), Microwave synthesis, spectral, thermal, 3D Molecular modeling analysis and antimicrobial activities of some transition metal complexes of Schiff bases derived from 5-brmo salicylaldehyde, J.Seb.Chem. Soc., 77, 1013-1029.

15. Ballhausen, C.J.,(1979), 'Molecular Electronic structure of Transition Metal Complexes', McGraw Hill, New York,

16. Sharma, A.L,; Singh, I.O.; Singh, M.A.; Singh, H.R.; Kadam, R.M.;Bhide, M.K.; Sastry, M.D., (2001), EPR studies on dichloromono (1-phenylamidino-o-alkylurea) copper(II) complexes. Evidence for field induced partial ordering in the solid state and some unusual features in solution, Trans. Met. Chem., 26, 532-537.

17. Benial, A.M.F.; Ramakrishnan, V.; Murugesan, R.; (2000), Single crystal EPR of $\mathrm{Cu}(\mathrm{C} 5 \mathrm{H} 5 \mathrm{NO})_{6}(\mathrm{BF} 4)_{2}$ : an example of admixed ground state, Spectrochim. Acta Part A 56, 2775-2781.

18. Raman, N.; Kulandaisamy, A.; Jeyasubramanian, K., (2004), Synthesis, structural characterization, redox, and antibacterial studies of 12-membered tetraaza macrocyclic $\mathrm{Cu}(\mathrm{II}), \mathrm{Ni}(\mathrm{II}), \mathrm{Co}(\mathrm{II}), \mathrm{Zn}$ (II), and $\mathrm{Vo}$ (IV) complexes derived from 1,2-(diimino-4'-antipyrinyl)-1,2-diphenylethane and o-phenylenediamine, Synth. React. Inorg. Met. Org. Chem., 34, 17-43.

19. Coombs, R.R.; Westcott, S.A.; Decken, A.; Baerlocher, F.J., (2005), Palladium(II) Schiff base complexes derived from sulfanimides and aminobenzothiazoles, Trans. Met. Chem. 30, 411-418.

20. Chohan, Z.H.; Munawar, A.; Supuran, C.T.; (2001), Transition metal ion complexes of Schiff bases: synthesis, characterization and antibacterial properties. Met. Based Drugs, 8, 137-143.

21. Chohan, Z.H.; Iqbal, M.S.; Aftab, S.K.,(2010), Design, synthesis, characterization and antibacterial properties of copper(II) complexes with chromone derived compounds, Appl. Organomet. Chem., 24, 47-56. 